\title{
PREFACE TO
}

\section{THE SECOND EDITION}

Children Are Artists was originally conceived for parents. So many of my friends and acquaintances had asked me to pass judgment on art work, to assure them that their children had or had not special talents, that I decided to write a book that would summarize current thinking about children's artistic expression. My aim was to keep the book short, to avoid any involvement with problems of technique, and to keep the terminology simple and nontechnical.

My publishers, however, were convinced that the work would be useful not only to parents, but to teachers, especially teachers in training. So the original manuscript was modified with elementary school teachers in particular in mind. Time has corroborated the publishers' judgment, for since its appearance ten years ago Children Are Artists has been adopted as a text in a large number of teacher-training institutions.

The present second edition has been revised to increase the scope of the book without changing its essential nature. Its previous success now makes it possible to include a collection of colored illustrations, thereby adding both information and delight. I have also attempted to summarize recent findings in the field of creativity. In the past ten years American educators have become increasingly concerned about what appears to be an overemphasis on learning facts and acquiring skills in our schools, frequently at the cost of developing creative patterns of behavior, resourcefulness, and an inquisitive attitude toward knowledge. The role of the arts as a stimulus to creative activity in all fields has been explored, and there has been considerable research of a psychological nature in the field of art education. I have purposely avoided any detailed reporting on the rather extensive studies that form an important part of current graduate research in art education, since the separate 
studies tend to be fragmentary and relate more to psychological theory than to educational practice. This in no sense denies the value of what is being accomplished, for as the theory of art education is strengthened by psychological and sociological disciplines, the practice of art education will be enriched. However, since my aim is to keep this volume concise and of practical value, I have attempted to summarize and generalize on current findings to the degree that they apply to general teaching practice rather than to explore the various separate studies.

I have also purposely avoided pronouncing upon the many problems related to schoolroom practice or the administration of art education programs in the public schools. A number of art educators, drawing upon a wealth of personal experience, have published excellent books summarizing their thinking and experience. It would be presumptuous for me with my limited experience in public schools to advise about classroom practice. I have also kept recipes and advice on processes to a minimum, since many good books on the craft and how-to-do-it level already exist. Instead, my hope is to strike directly at the heart of the role of the visual arts in education, to present a guiding philosophic and psychological framework based on the chronological stages through which a child's artistic expression evolves, and to relate this framework to the parent-teacher-child relationship. Given this broad orientation I trust the intelligence of parents and teachers to solve specific practical problems as they occur.

I would like to express my appreciation of the help that the following people and institutions have given me. For illustrations I am indebted to Mrs. Maxwell Arnold for Fig. 24; to Mrs. Elizabeth Aronstein for Plate VI; to Mrs. Felix Bloch for Fig. 33; to Mr. William Bowman for Fig. 25; to Mrs. William Carter for Figs. 9, 10, and 11; to Mrs. William Crosten for Figs. 15, 16, 17, and 41; to Mrs. Sidney Davis for Fig. 28; to Mrs. Edward Farmer of the Palo Alto Senior High School for Figs. 44, 48, 57, and 58; to Dr. Ray Faulkner for Figs. 1, 19, and 20, and Plate I; to Mr. Mike Fromhold for Figs 51 and 52; to Mr. Paul Glenn for Plates II, III, VII, and VIII; to Mrs. Jack Granoff for Fig. 22; to Mr. Alvin Hansen for Figs. 2, 14, 18, and 29; to Mr. Douglas Hofstadter for Fig. 56; to Mrs. Susan Irwin of the San Francisco City Schools for Figs. 26 and 33; to Mr. Matt Kahn for Figs. 43 and 59; to the Leupp Boarding School, Winslow, Arizona, for Fig. 42; to Mrs. Charles Lindstrom of the De Young Museum, San Francisco, for Fig. 45; to Mrs. Francis Marshall for Fig. 7; to Mr. Leon Mead of the Florida State University, Tallahassee, Florida, for Fig. 38; to the National Art Education Association for permission to reproduce Figs. 27, 37, and 47 from the Association's year- 
PREFACE - ix

book, This Is Art Education, 1952; to Mr. Richard Rankin for Figs. 21, 30, 31, and 32; to Mr. Robert Sterling of the Palace of the Legion of Honor, San Francisco, for Figs. 5, 35, and 49; and to Mr. Wesley Williams of the Terman Junior High School, Palo Alto, for Figs. 34 and 53; to Mr. Alvin Zelver for Plates IV and V.

The photographing of Figs. 2-12, 14-18, 21, 23, 29-33, 39, 45, 52, 55, and 56 was done by Mrs. Rose Mandel. Mr. Burton W. Crandall photographed Figs. 4, 13, 35, 36, 40, 41, 44, 48, 51, and 57; Mr. Richard Keeble Fig. 42, and the Stanford Photography Department Figs. 22, 24, 25, $28,33,43,55,56$, and 59 . For their patience and interest I am very grateful.

Most of the illustrations have been used without the artists' knowledge. Often the artist forgot to sign his name. I owe a special debt to the many children and adolescents whose works inspired this book and now serve as illustrations for it; similarly I feel much indebted to the parents and teachers who encouraged the children to express themselves and who collected and saved their works.

I could well have dedicated the book to all these people, but I have reserved that notice for two who have helped throughout its preparation and before. The book is thus dedicated to my wife, Mildred, and my son, Louis, who helped in many ways, in particular by producing illustrations Figs. 4, 8, 12, 13, 23, 36, 39, 40, 46, 50, 54, and 55 .

Stanford University

D. M. M.

July 1963 
